\title{
A study on the state of knowledge of managers of construction sites in the field of occupational safety
}

\author{
Wojciech Drozd ${ }^{1}$, Marcin Kowalik ${ }^{1}$, \\ ${ }^{1,2}$ Cracow University of Technology, ul. Warszawska 24, 31-155 Cracow, Poland
}

\begin{abstract}
The construction site and its elements create circumstances that are conducive to the formation of risks to work safety during the execution of works. Analysis indicates the critical importance of these factors in the set of characteristics that describe the causes of accidents in the construction industry. They are indicated as important factors having an impact on risks, and increasingly are the subject of studies on work safety in construction. The research focused on as well as the awareness of health and safety of site managers - who perform independent functions in construction, legally involved in the construction process. Main substantive tasks included comparison of observed values with expected values in regard to characteristics related to health and safety awareness among site managers.
\end{abstract}

\section{Introduction}

The work of people who perform construction functions themselves, in particular construction managers combines prestige and great responsibility. On their work depends the final effect of construction works performed or supervised, in legal and technical functions.

The construction manager stands out among other participants of the construction process performing an independent technical function in the construction process.

The construction manager is always one. In the light of law, he is primarily responsible for maintaining safety on the construction site, regardless of whether the construction works are carried out, or stopped for months $[1,2,3]$. His duty is to preserve the work safety, and thus the construction manager, is responsible for checking whether the employees have been provided by the employer with personal protective equipment, such as helmets, appropriate footwear, gloves or braces. The construction manager is to check the medical certificates of employees, for example the lack of contraindications to work at height and check whether the mechanical construction equipment fulfils the legal requirement, for example, of the certificate of the Office of Technical Inspection. The site manager should conduct workstation training and record this fact in the construction documentation. Any irregularities found in this respect should disqualify an employee or equipment. He is responsible for all irregularities and will not excuse him from responsibility in case of an accident on the construction site and it will be found that he has not fulfilled his obligations.

It should be remembered that the construction manager is responsible for the construction site taken over and for all the events taking place there throughout the period in which he performs his function. It depends on him how the construction works will be carried out and whether the work he supervises will be carried out in accordance with the law, without unnecessary exposure to danger of all employees subordinate to him. Disregarding the rules leads consequently to an accident at the site and exposes the participants of the construction process to liability.

Daily reality on construction sites shows that people performing the functions of construction managers, responsible for the safe implementation of works - do not really know the obliging regulations in the field of occupational safety or do not always apply them in practice, or neglect while managing performance. Having the above in mind, the actual level of knowledge was examined in the field of work safety among construction managers.

\section{Research methodology}

The research used a written knowledge test containing 13 questions related to the issues of work safety at the construction site. In order to obtain best results, the test was carried out anonymously, under controlled conditions, among 42 people (out of 100 intended) holding building qualifications, managing construction sites in the Małopolska region. The test contained the following questions (Table 1):

Table 1. Questions to construction managers in the field of occupational safety. Source: own.

\begin{tabular}{|l|l|}
\hline The scope of questions & The content of the questions \\
\hline $\begin{array}{l}\text { Internship - } \\
\text { employment }\end{array}$ & $\begin{array}{r}\text { P1. How long do you run the } \\
\text { construction works by }\end{array}$ \\
\hline
\end{tabular}

* Corresponding author: wdrozd@ Ztob.pk.edu.pl 


\begin{tabular}{|c|c|}
\hline & yourself. \\
\hline Legal regulations & $\begin{array}{l}\text { P2. Please provide known to your } \\
\text { legal acts regulating work } \\
\text { safety rules in construction. } \\
\text { P3. Please list the basic duties of } \\
\text { the construction manager in } \\
\text { the aspect of work safety, } \\
\text { resulting from legal } \\
\text { regulations. }\end{array}$ \\
\hline Technical supervision & $\begin{array}{l}\text { P4. Please provide familiar rules } \\
\text { regarding the technical } \\
\text { supervision of construction } \\
\text { equipment. }\end{array}$ \\
\hline $\begin{array}{l}\text { Regulations } \\
\text { in practice }\end{array}$ & $\begin{array}{l}\text { P5. Please indicate construction } \\
\text { works that are particularly } \\
\text { dangerous. } \\
\text { P6. Please provide basic rules for } \\
\text { work safety when } \\
\text { implementing any } \\
\text { construction works. }\end{array}$ \\
\hline Protection & $\begin{array}{l}\text { P7. Please specify the basic } \\
\text { collective protection } \\
\text { measures that are applicable. } \\
\text { P8. Please list basic personal } \\
\text { protective equipment, used in } \\
\text { construction. }\end{array}$ \\
\hline Training & $\begin{array}{l}\text { P9. Please list the employee } \\
\text { workplaces training courses } \\
\text { that are carried out on } \\
\text { construction sites. }\end{array}$ \\
\hline $\begin{array}{l}\text { Health and safety } \\
\text { documentation }\end{array}$ & $\begin{array}{l}\text { P10. Please quote the health and } \\
\text { safety documents in the } \\
\text { construction process. } \\
\text { P11. Please indicate the } \\
\text { construction works for } \\
\text { which drawing up the } \\
\text { "BIOZ" plan is obligatory. }\end{array}$ \\
\hline $\begin{array}{l}\text { Professional and } \\
\text { disciplinary } \\
\text { responsibility }\end{array}$ & $\begin{array}{l}\text { P12. Please indicate examples of } \\
\text { conduct of the construction } \\
\text { manager subject to } \\
\text { professional and disciplinary } \\
\text { liability }\end{array}$ \\
\hline $\begin{array}{l}\text { Post-accident } \\
\text { proceedings }\end{array}$ & $\begin{array}{l}\text { P13. Please provide basic } \\
\text { procedures for post-accident } \\
\text { proceedings }\end{array}$ \\
\hline
\end{tabular}

Answers received to questions: $\mathrm{P} 2$ to $\mathrm{P} 13$ were checked for correctness and, in order to allow for analysis, coded (Table $2 \mathrm{a}$ and $2 \mathrm{~b}$ ) as:

1 - poorly (the answer is insufficient or no answer),

2 - good (the answer is incomplete),

3 - very good (the answer is exhaustive), and to question P1:

4 - up to 2 years,

5 - 3 to 5 years,

6 - 6 to 10 years,

7 - 11 to 14 years,

$\mathbf{8}$ - over than 15 years.

Table 2a. Coded answers of the reviewed construction managers to questions (Table 1) in the field of work safety. Source: own.

\begin{tabular}{|c|c|c|c|c|c|c|}
\hline \multirow{2}{*}{$\begin{array}{c}\text { Sl. } \\
\text { No. }\end{array}$} & $\begin{array}{c}\text { Internship - } \\
\text { employment }\end{array}$ & \multicolumn{2}{|c|}{$\begin{array}{c}\text { Knowledge } \\
\text { of legal } \\
\text { regulations }\end{array}$} & $\begin{array}{c}\text { Technical } \\
\text { supervision }\end{array}$ & \multicolumn{2}{|c|}{$\begin{array}{c}\text { Observing the } \\
\text { rules in } \\
\text { practice }\end{array}$} \\
\cline { 2 - 7 } & P 1 & P 2 & P 3 & P 4 & P 5 & P 6 \\
\hline 1 & 7 & 3 & 3 & 1 & 3 & 1 \\
\hline 2 & 6 & 2 & 3 & 2 & 2 & 1 \\
\hline
\end{tabular}

Table 2b. Coded answers of the surveyed construction managers to questions (Table 1) in the field of work safety (continued). Source: own.

\begin{tabular}{|c|c|c|c|c|c|c|}
\hline \multicolumn{2}{|c|}{ Protection } & Training & \multicolumn{2}{|c|}{$\begin{array}{c}\text { Health and } \\
\text { safety } \\
\text { documentation }\end{array}$} & $\begin{array}{c}\text { Professional } \\
\text { and } \\
\text { disciplinary } \\
\text { responsibility }\end{array}$ & $\begin{array}{c}\text { Post- } \\
\text { accident } \\
\text { proceedings }\end{array}$ \\
\hline P 7 & P 18 & P 9 & P10 & P 11 & P 12 & P 13 \\
\hline 2 & 3 & 2 & 1 & 3 & 3 & 3 \\
\hline 3 & 2 & 3 & 2 & 2 & 2 & 3 \\
\hline
\end{tabular}

Ordinal numbers (Sl.No.) are the same as consecutive, examined numbers of construction managers, while the columns show the numbers of subsequent questions: from P1 to P13 (Table 1) and the answers verified in terms of correct-ness, coded as digits. For editorial reasons, only two examples of observations are quoted.

\section{Results of selected couple questions}

The significance of the dependability for categorized variables (responses to P1 - P13) was verified by Pearson Chi-square $\left(\chi^{2}\right)$ test $[4,5]$. The test is based on the possibility to calculate the expected numbers in a bipartite table (i.e., the numbers that we would expect if there was no relationship between variables). The value of $\chi^{2}$ statistics and the level of its significance depend on the total number of awaited observations and the number of cells in the table. Relatively small deviations of relative frequencies in cells from expected ones turn out to be significant if number of examples is large enough.

The basic assumption for the use of the $\chi^{2}$ test (except sample randomness) was intended to achieve results in a form in which the expected frequencies did not appear too small. The reason is in the fact that chi-square test determines probabilities in individual cells and if any numbers will be for instance below 5, then the assessments of these probabilities may show themselves not sufficiently precise. In such situations, one of the possible solutions is the use of more complicated calculation methods, i.e. Fisher's exact test. 


$$
\mathrm{F}=\mathrm{S}_{\mathrm{x}}^{2} / \mathrm{S}^{2} \mathrm{y}
$$

$$
\begin{aligned}
& \mathrm{x}-\quad-\text { statistical tests, } \\
& \mathrm{y} \quad-\text { statistical tests, } \\
& \mathrm{S}_{\mathrm{x}}^{2}, \mathrm{~S}_{\mathrm{y}}^{2} \quad-\text { sample variances. }
\end{aligned}
$$

The strength of interrelations between variables was examined using the Spearman rank correlation coefficient (Sperman's r).
The research was reduced to the tests of significance of differences, between the variables concerning subsequent questions.

Descriptive analysis of the test was omitted.

The results of the $\chi^{2}$ test, between the pairs of variables concerning individual questions, in many cases show statistically significant dependencies. Table 3 shows the dependencies between all questions. Their strength was examined using the Spearman rank correlation coefficient. Significant results are marked in red [6, 7]. The closer the coefficient value is to $1 /-1$, the stronger the positive / negative relation between variables

Table 3. Sperman rank factors. Source: own.

\begin{tabular}{|c|c|c|c|c|c|c|c|c|c|c|c|c|c|}
\hline & P1 & P2 & P3 & P4 & P5 & P6 & P7 & P8 & P9 & P10 & P11 & P12 & P13 \\
\hline P1 & 1,00 & 0,10 & $-0,15$ & 0,12 & $-0,01$ & $-0,11$ & 0,15 & 0,28 & 0,21 & 0,21 & 0,05 & 0,16 & 0,33 \\
\hline P2 & 0,10 & 1,00 & 0,09 & 0,12 & 0,15 & $-0,01$ & $-0,05$ & 0,06 & 0,23 & 0,54 & $-0,16$ & $-0,05$ & 0,02 \\
\hline P3 & $-0,15$ & 0,09 & 1,00 & 0,12 & $-0,21$ & $-0,12$ & 0,17 & $-0,16$ & $-0,22$ & $-0,03$ & $-0,02$ & 0,09 & $-0,36$ \\
\hline P4 & 0,12 & 0,12 & 0,12 & 1,00 & 0,08 & $-0,09$ & 0,23 & 0,09 & 0,07 & 0,34 & 0,28 & $-0,17$ & 0,10 \\
\hline P5 & $-0,01$ & 0,15 & $-0,21$ & 0,08 & 1,00 & 0,68 & $-0,07$ & 0,35 & 0,40 & 0,34 & 0,03 & 0,39 & 0,31 \\
\hline P6 & $-0,11$ & $-0,01$ & $-0,12$ & $-0,09$ & 0,68 & 1,00 & $-0,02$ & 0,22 & 0,20 & $-0,03$ & $-0,11$ & 0,27 & 0,13 \\
\hline P7 & 0,15 & $-0,05$ & 0,17 & 0,23 & $-0,07$ & $-0,02$ & 1,00 & $-0,11$ & $-0,54$ & 0,08 & 0,09 & $-0,18$ & $-0,10$ \\
\hline P8 & 0,28 & 0,06 & $-0,16$ & 0,09 & 0,35 & 0,22 & $-0,11$ & 1,00 & 0,61 & 0,22 & 0,36 & 0,31 & 0,46 \\
\hline P9 & 0,21 & 0,23 & $-0,22$ & 0,07 & 0,40 & 0,20 & $-0,10$ & 0,61 & 1,00 & 0,33 & 0,18 & 0,22 & 0,44 \\
\hline P10 & 0,21 & 0,54 & $-0,03$ & 0,34 & 0,34 & $-0,03$ & 0,08 & 0,22 & 0,33 & 1,00 & 0,08 & 0,08 & 0,32 \\
\hline P11 & 0,05 & $-0,16$ & $-0,02$ & 0,28 & 0,03 & $-0,11$ & 0,09 & 0,36 & 0,18 & 0,08 & 1,00 & 0,03 & 0,03 \\
\hline P12 & 0,62 & $-0,05$ & 0,09 & $-0,17$ & 0,39 & 0,27 & $-0,18$ & 0,31 & 0,22 & 0,08 & 0,03 & 1,00 & 0,30 \\
\hline P13 & 0,33 & 0,02 & $-0,36$ & 0,10 & 0,31 & 0,13 & $-0,10$ & 0,46 & 0,44 & 0,32 & 0,03 & 0,30 & 1,00 \\
\hline
\end{tabular}

This coefficient evaluates the monotonic (growing decreasing sequence) nature of dependence. It accepts extreme values if the cases ordered in relation to the value of one and the other variables are set in the same $(\mathrm{r}=1)$ or inverse order $(\mathrm{r}=-1)$. The coefficient does not assume a linear relationship between variables and is determined not directly on the basis of variable values, but on the basis of rank (order). It allows to reduce the result load with outstanding values.

Spearman's factor $\mathbf{r}$ can range from -1 to 1 . A value close to -1 indicates a strong negative correlation, close to "1" strong positive correlation and close "0" no correlation.

$$
R=1-\frac{6 \sum_{i=1}^{N} d_{i}^{2}}{N\left(N^{2}-1\right)}
$$

where:

$R \quad-\quad$ Spearman's rank correlation coefficient, $\sum_{i=1}^{N} d_{i}^{2} \quad-$ the sum raised to the square of differences between consecutive rank pairs,

$N \quad-\quad$ number of rank pairs.

The interpretation of results for selected pairs of questions is presented below

- with the highest Spearman rank correlation coefficient:
- P5: Please indicate construction works that are particularly dangerous vs P6: Please provide basic rules for work safety in the implementation of any kind of construction works.

Table 4. Percentage share of answers: P5 vs P6. Source: own.

\begin{tabular}{|c|c|c|c|c|}
\hline \multirow{2}{*}{$\boldsymbol{P 5}$} & \multicolumn{4}{|c|}{ P6 } \\
\cline { 2 - 5 } poorly & poorly & good & very good & total \\
\hline good & $0,0 \%$ & $66,7 \%$ & $13,3 \%$ & $35,7 \%$ \\
\hline very good & $0,0 \%$ & $21,7 \%$ & $78,3 \%$ & $54,8 \%$ \\
\hline general & $7,1 \%$ & $0,0 \%$ & $100,0 \%$ & $9,5 \%$ \\
\hline
\end{tabular}

The $\chi^{2}$ test showed that there is a relationship between variables P5 and P6. From the chart below (Figure. 1) we can read which answers are changing in a different way. 
Fig. 1. Interaction diagram "P5" x "P6". Source: own.

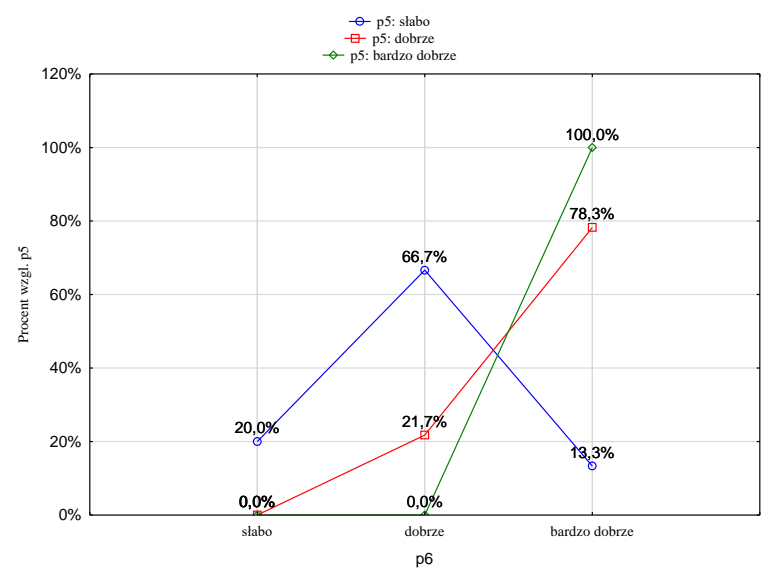

In the shown graph we observe that $100 \%$ of site managers who know very well which works are especially dangerous on the construction site and also very well know the basic principles of work while carrying out any construction works. $67 \%$ of managers who have a weaker knowledge concerning particularly dangerous works - know well the principles of work safety in the implementation of any kind of construction works. On the other hand, over $78 \%$ of those who know kinds of works that are particularly dangerous know very well the principles of work safety in the implementation of any construction works. Worrying is the fact that $20 \%$ of managers who do not know much about particularly dangerous works do not know the basic principles of work safety while implementing any kind of construction works.

P12: Please indicate examples of conduct of the construction manager subject to professional and disciplinary liability vs. P1: How long do you run the construction works by yourself.

Table 5. Percentage share of answers: P 12 vs P1. Source: own.

\begin{tabular}{|c|c|c|c|c|c|c|}
\hline \multirow{2}{*}{ P12 } & \multicolumn{6}{|c|}{ P1 } \\
\cline { 2 - 7 } & $\begin{array}{c}\text { up to 2 } \\
\text { years }\end{array}$ & $\begin{array}{c}\text { 3 to 5 } \\
\text { years }\end{array}$ & $\begin{array}{c}\text { 6 to 10 } \\
\text { years }\end{array}$ & $\begin{array}{c}\mathbf{1 1} \text { to 14 } \\
\text { years }\end{array}$ & $\begin{array}{c}\text { over } \\
\text { than } \\
\text { 15 years }\end{array}$ & total \\
\hline poor & $10,0 \%$ & $60,0 \%$ & $0,0 \%$ & $30,0 \%$ & $0,0 \%$ & $23,8 \%$ \\
\hline good & $50,0 \%$ & $33,3 \%$ & $4,2 \%$ & $4,2 \%$ & $8,3 \%$ & $57,1 \%$ \\
\hline $\begin{array}{c}\text { very } \\
\text { good }\end{array}$ & $12,5 \%$ & $0,0 \%$ & $25,0 \%$ & $37,5 \%$ & $25,0 \%$ & $19,0 \%$ \\
\hline $\begin{array}{c}\text { gener } \\
\text { al }\end{array}$ & $33,3 \%$ & $33,3 \%$ & $7,1 \%$ & $16,7 \%$ & $9,5 \%$ & $100,0 \%$ \\
\hline
\end{tabular}

The $\chi^{2}$ test showed that there is a relationship between the P12 and P1 variables. From the chart presented below (Figure 2), we can read which answers are changing in a different way.
Fig. 2. Interaction diagram "P12" x "P1". Source: own

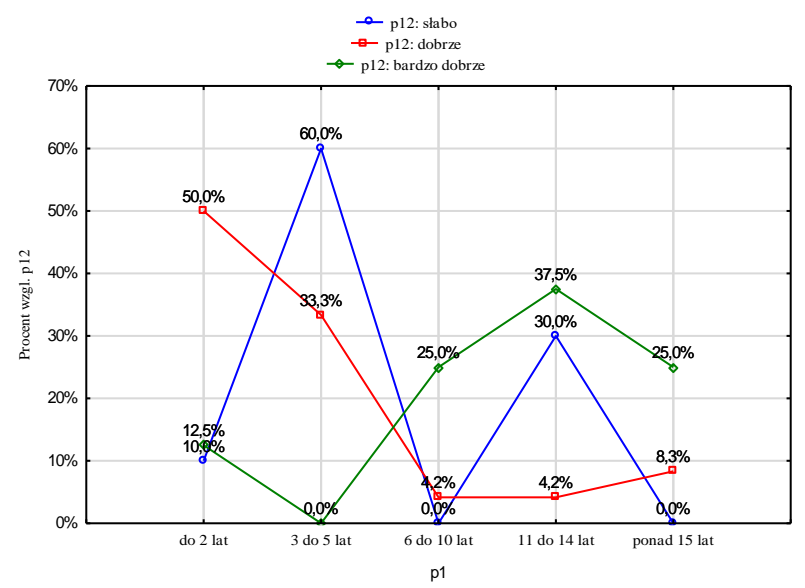

In the graph presented we may notice that among construction managers, who poorly knew examples of conduct subject to professional and disciplinary liability, the majority gained experience during managing independent construction in the period between 3 to 5 years $(60 \%)$ and in the range from 11 to 14 years $(30 \%)$. Those managers who knew well the examples of conduct subject to professional and disciplinary liability, most often had managed the independent construction of buildings in periods of up to 2 years $(50 \%)$ and from 3 to 5 years $(33.3 \%)$. A very good knowledge of the proceedings subject to liability was demonstrated by persons with practice between 11 and 14 years $(37.5 \%)$ and from 6 to 10 and over 15 years (by $25 \%$ each). In general, a longer experience in self-employed construction corresponds to a greater degree of very good knowledge of proceedings subject to professional liability and disciplinary.

For pairs of statistically significant questions with a high Spearman rank correlation coefficient $(\mathrm{R}>0.5)$, also belong:

P2: Please provide known to you legal acts regulating work safety rules in construction vs

P10: Please quote the health and safety documents in the construction process $(\mathrm{R}=0.54)$,

P9: Please list the employee workplaces training courses that are carried out on construction sites vs

P8: Please list basic personal protective equipment, used in construction $(\mathrm{R}=0.61)$ and

P7: Please specify the basic collective protection measures that are applicable

in construction vs

P9: Please list the employee training courses that are carried out on construction sites.

\section{Summary}

The test conducted among the construction managers and superintending self-managing construction works, included 13 questions in the area: knowledge of legal acts, technical supervision, compliance with Health and Safety regulations in practice, protection measures, training, Health and Safety documentation, including the preparation of a safety plan and health protection, professional and disciplinary liability and post-accident 
proceedings. The results are significant. The examined state of knowledge does not reach too high a level. The results of the test allow to note some deficiencies in the surveyed managers, in terms of knowledge of the applicable provisions regarding work safety. Most of the answers given to individual questions are good but not very good. In the case of knowledge of the provisions on technical supervision, Health and Safety documentation, particularly dangerous works and professional and disciplinary liability, the most deficiencies and gaps were noted. The increase in "safety awareness" for those involved in the construction process may bring some improvement in the image of Polish construction in this aspect.

\section{REFERENCES}

1. Drozd W. (2012). Professional responsibility and disciplinary in construction, Archives of Institute of Civil Engineering, Wyd. Poznan University of Technology, No. 13/2012, pp. 63-67.

2. Drozd W . (2016). Characteristics of the construction site in the aspect of occupational safety hazards, Journal of Civil Engineering, Environment and Architecture, Rzeszów University of Technology, January - March 2016, pp. 165-172.

3. Hoła B. (2011). Requirements for safety regulations on the construction site, Building Materials, No. 5, 2011, pp. 86-88.

4. Agrawal R., Srikant R. (1994). Fast Algorithms For Mining Association Rules in Large Databases, Proceedings of the 20th International Conference on Very Large Databases, pp. 487-499.

5. Breiman L., Friedman J., Stone C.J., Olshen R.A. (1984). Classification and Regression Trees, Wadstworth Statistics/Probability.

6. R Core Team (2016). R: A language and environment for statistical computing, R Foundation for Statistical Computing. https://www.Rproject.org/.

7. StatSoft, Inc. (2014). STATISTICA (data analysis software system), version 12. www.statsoft.com 